\title{
積層円板の自由振動特性に及ぼす層間はく離の影響*
}

\author{
有 冨 正 男*1, 師 岡 優*2, 福 岡 和 樹*3 \\ 小田 美紀男*1, 戸谷 顛 之*1

\section{Effect of Delaminations on Free Vibration Characteristics of Circular Laminated Plates}

\author{
Masao ARITOMI*4, Yuu MOROOKA, Kazuki FUKUOKA, \\ Mikio ODA and Masayuki TOYA \\ ${ }^{* 4}$ Department of Mechanical Engineering, Kagoshima University, \\ 1-21-40 Korimoto, Kagoshima-shi, Kagoshima, 890-0065 Japan
}

\begin{abstract}
The influence of multiple disk-shaped delaminations of a same size on the natural vibration characteristics of the clamped circular laminated plates has been investigated. The basic assumptions are that the delaminated layers are contacting one another and inplane inertia effects are neglected. The equation of motion and constitutive relations for a plate are expressed in term of transverse deflection and stress function. Analyses and experiments are carried out for the natural frequencies. Theoretical and experimental results agree well, which validates the analytical model assumed in present study. It is shown that the effect of the in-plane displacements of the referencesurface on the free vibration characteristics of laminated plates is small, by comparing the present results with hinged model's results which are neglected the in-plane displacements.
\end{abstract}

Key Words : Free Vibration, Vibration of Continuous System, Delamination, Circular Laminated Plate, Natural Frequency

\section{1. まえがき}

異種材を接着した積層材料は, 材料特性の不連続が 存在するため, 異物などとの衝突により外側から観察 しづらい層間はく離などの損傷が発生する.この損傷 により剛性や強度が低下するが，積層材の断熱材が衝 撃や振動によって剥がれ落ちて大事故に至る場合を考 えると, 動的横荷重によるはく離進展のメカニズムを 明らかにすることは重要な課題といえる. その際, 層 間はく離が積層材料の振動特性に及ぼす影響を調査し ておく必要がある.

層間はく離が積層はりの動的挙動に及ぼす影響を調 查した研究 ${ }^{(1)}$ ( $^{(8)}$ は数多く見受けられるが, 積層板に 関する研究は少ない. たとえば, 関根ら ${ }^{(9)}$ は内部に一 個の円形はく離を有する積層長方形板の剛体球による 衝突応答を解析している. 著者ら(10) 〜(13) は, はく離を 有する異種材積層板の振動問題に対して, 最も簡単な

* 原稿受付 2008 年 7 月 16 日.

*1 正員, 鹿児島大学工学部( $890-0065$. 鹿児島市郡元 1-2140).

*2 鹿児島大学大学院理工学研究科。

*3 (株) クボタ (昰 556-8601 大阪市浪速区數津東 1-2-47).

E-mail : aritomi@mech.kagoshima-u.ac.jp
円形はく離を有する積層円板の自由振動を取り上げ, 工学基礎としての理論解析と実験を行っている.また 末益ら ${ }^{(14)(15)}$ は衝撃点下に発生する積層円板中の円形多 重層間はく離が横荷重により進展する問題を研究して いる.

本報は前報 ${ }^{(13)}$ に引き続き，異種材からなる $\mathrm{N}$ 層の 積層円板が，その中心部に大きさの等しい円形の多重 層間はく離を有する場合の自由振動を取り上げる．た だし，面内変形の影響を考慮した理論解析は，前報で は軸対称振動についてのみ行ったが, 本報では一般の 振動モードの自由振動について行う. その際, 面内の 慣性力は無視できるものとして応力関数を導入し，面 内変位の影響を考慮した運動方程式とひずみの適合条 件を導き，固有振動数と固有振動モ一ドを求める. 同 時に, 面内変形の影響を無視し，はく離端をヒンジ止 めと仮定した従来の解析モデルの理論結果 ${ }^{(13)}$ と比較 し, 面内変形が振動特性に及ぼす影響は小さく無視で きることを明らかにする. また, 二層板 ${ }^{(11)}$ ，三層板 ${ }^{(12)}$ および今回実験を行った四層板の一般の振動モードに 対して測定した固有振動数と理論結果を比較し, 解析 モデルの妥当性を検証する. 


\section{2. 基 礎 式}

$2 \cdot 1$ 皘層部分の支配方程式 本論文では，層間はく離 か㵾層板の自由振動に及ぼす基本的な影響を調査するため, 各層の板は複合材料ではなく，均質・等方性材料とする. 図1に示すような, $\mathrm{N}$ 枚の異種材を接着した半径 $R$ の積層 円板が，各層間の円板中心に半径 $c$ の大きさの等しい $\mathrm{N}-1$ 個の円形はく離を有する場合を考光る．積層円板の上面か $ら k$ 番目の層の厚さを $h_{k}$, 絎弾性倸数を $E_{k}$, ポアソン比を $\nu_{k}$, 密度を $\rho_{k}$, 伸乙阔性之曲计成性を $C_{k}, D_{k}$ とする. ま，板の上面から クの距離のところに基準面を設け，板上 面から第 $k$ 層の中央面までの距離を $H_{k}$, 基準面から第 $k$ 層 の中央面までの跑離を $d_{k}$ として, 各諸量を式 (1) のように 定める。

$$
\begin{aligned}
& C_{k}=\frac{E_{k} h_{k}}{1-v_{k}^{2}}, D_{k}=\frac{E_{k} h_{k}^{3}}{12\left(1-v_{k}^{2}\right)}, H_{k}=\sum_{i=1}^{k} h_{i}-\frac{h_{k}}{2} \\
& d_{k}=H_{k}-\eta, h=\sum_{k=1}^{N} h_{k}, \rho h=\sum_{k=1}^{N} \rho_{k} h_{k} \\
& D_{s}=\sum_{k=1}^{N} D_{k}, D_{12 s}=\sum_{k=1}^{N} v_{k} D_{k}
\end{aligned}
$$

本報では, 微小振幅の自由曲げ振動を取扱う. まず積層円板に作用する面内力 $N_{r}, N_{\theta}, N_{r \theta}$, 曲げモ一メント $M_{r}, M_{\theta}$ ，ねじりモ一メント $M_{r \theta}$ は $\left[\begin{array}{l}N_{r} \\ N_{\theta} \\ N_{r \theta} \\ M_{r} \\ M_{\theta} \\ M_{r \theta}\end{array}\right]=\left[\begin{array}{cccccc}C & C_{12} & 0 & B & B_{12} & 0 \\ C_{12} & C & 0 & B_{12} & B & 0 \\ 0 & 0 & C_{r \theta} & 0 & 0 & B_{r \theta} \\ B & B_{12} & 0 & D & D_{12} & 0 \\ B_{12} & B & 0 & D_{12} & D & 0 \\ 0 & 0 & B_{r \theta} & 0 & 0 & D_{r \theta}\end{array}\right]\left[\begin{array}{c}\varepsilon_{r}^{0} \\ \varepsilon_{\theta}^{0} \\ \varepsilon_{r \theta}^{0} \\ \kappa_{r} \\ \kappa_{\theta} \\ \kappa_{r \theta}\end{array}\right]$

で与えられる. ただし，基準面のひずみ $\varepsilon_{r}^{0}, \varepsilon_{\theta}^{0}, \varepsilon_{r \theta}^{0}$ と曲 率 $\kappa_{r}, \kappa_{\theta}, \kappa_{r \theta}$ は

$\varepsilon_{r}^{0}=\frac{\partial u^{0}}{\partial r}, \varepsilon_{\theta}^{0}=\frac{1}{r}\left(u^{0}+\frac{\partial v^{0}}{\partial \theta}\right)$ $\varepsilon_{r \theta}^{0}=\frac{1}{r}\left(\frac{\partial u^{0}}{\partial \theta}-v^{0}\right)+\frac{\partial v^{0}}{\partial r}$ $\kappa_{r}=-\frac{\partial^{2} w}{\partial r^{2}}, \kappa_{\theta}=-\left(\frac{1}{r} \frac{\partial w}{\partial r}+\frac{1}{r^{2}} \frac{\partial^{2} w}{\partial \theta^{2}}\right)$ $\kappa_{r \theta}=-2\left(\frac{1}{r} \frac{\partial^{2} w}{\partial r \partial \theta}-\frac{1}{r^{2}} \frac{\partial w}{\partial \theta}\right)$

と表わされる. 式（2）中の異種材からなる $\mathrm{N}$ 層積 層円板の伸び風性 $C, C_{12}, C_{r \theta}$, 伸びと曲げの連成

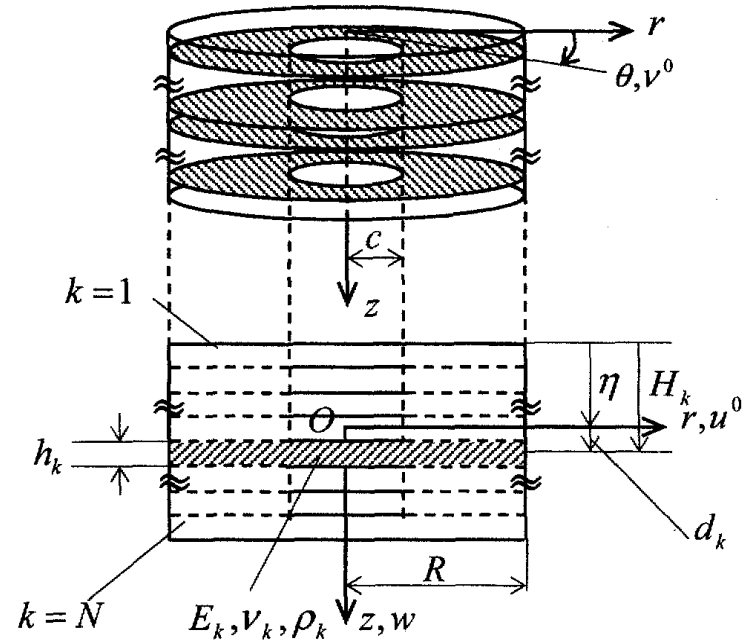

Fig. 1 Geometry of a circular laminated plate containing multiple disk-shaped delaminations

剛性 $B, B_{12}, B_{r \theta}$, 曲け風性 $D, D_{12}$ ， ねじり剛性 $D r \theta$ は，式（1）の諸量を用いると

$C=\sum_{k=1}^{N} C_{k}, C_{12}=\sum_{k=1}^{N} v_{k} C_{k}, C_{r \theta}=\frac{1}{2}\left(C-C_{12}\right)$

$B=\sum_{k=1}^{N} d_{k} C_{k}, B_{12}=\sum_{k=1}^{N} v_{k} d_{k}^{*} C_{k}, B_{r \theta}=\frac{1}{2}\left(B-B_{12}\right)$

$D=\sum_{k=1}^{N}\left(D_{k}+d_{k}^{2} C_{k}\right), D_{12}=\sum_{k=1}^{N} v_{k}\left(D_{k}+d_{k}^{2} C_{k}\right)$

$D_{r \theta}=\frac{1}{2}\left(D-D_{12}\right)$

と与えられる ${ }^{(12)}$ ，曲け剛性とねじり剛性，および連 成剛性は基準面の位置 クによって变化する.

座標原点 O は基準面の円板の中心にとり，座標軸は それぞれ座標原点から半径方向と円周方向に沿って $r$ 軸と $\theta$ 軸を，垂直下方に $z$ 軸を定める．また，基淮面 の $r$ と $\theta$ 方向の面内変位を $u^{0}, v^{0}, z$ 方向のたわみを $w$ とする. 座標 $r$, 時間 $t$, たわみ $w$, 面内変位 $u^{0}, v^{0}$, 面内力 $N_{r}, N_{\theta}, N_{r}$ および各諸量を

$\left(\bar{w}, \bar{u}^{0}, \bar{v}^{0}, \bar{\eta}\right)=\left(w, u^{0}, v^{0}, \eta\right) / h,(\xi, \bar{c})=(r, c) / R$ $\left(\bar{C}, \bar{C}_{12}\right)=\left(C, C_{12}\right) \frac{h^{2}}{D},\left(\bar{B}, \bar{B}_{12}\right)=\left(B, B_{12}\right) \frac{h}{D}$ $\bar{D}_{12}=\frac{D_{12}}{D}, \quad \tau=\frac{t}{R^{2}} \sqrt{\frac{D}{\rho h}}$

$\left(\bar{N}_{r}, \bar{N}_{\theta}, \bar{N}_{r \theta}\right)=\left(N_{r}, N_{\theta}, N_{r \theta}\right) \frac{R^{2}}{D}$

のように無次元化する．面内変位 $u^{0}, v^{0}$ はたわみ $w$ に比べて小さく，面内方向の慣性力が無視できる ${ }^{(16)}$ とすると, $r$ と方向の力のつり合い式は 


$$
\left.\begin{array}{l}
\frac{1}{\xi}\left(\bar{N}_{r}-\bar{N}_{\theta}\right)+\frac{\partial \bar{N}_{r}}{\partial \xi}+\frac{1}{\xi} \frac{\partial \bar{N}_{r \theta}}{\partial \theta}=0 \\
\frac{1}{\xi} \frac{\partial \bar{N}_{\theta}}{\partial \theta}+\frac{2}{\xi} \bar{N}_{r \theta}+\frac{\partial \bar{N}_{r \theta}}{\partial \xi}=0
\end{array}\right\}
$$

となる. この式 (6) を恒等的に満足する次の無次元応 力関数 $F$ を導入する.

$$
\left.\begin{array}{l}
\bar{N}_{r}=\frac{1}{\xi} \frac{\partial F}{\partial \xi}+\frac{1}{\xi^{2}} \frac{\partial^{2} F}{\partial \theta^{2}} \\
\bar{N}_{\theta}=\frac{\partial^{2} F}{\partial \xi^{2}}, \quad \bar{N}_{r \theta}=-\frac{\partial}{\partial \xi}\left(\frac{1}{\xi} \frac{\partial F}{\partial \theta}\right)
\end{array}\right\}
$$

微小振幅の自由曲げ振動に対する運動方程式とひずみ の適合条件式は

$$
\begin{aligned}
& \frac{\partial^{2} \bar{w}}{\partial \tau^{2}}+\left\{1-K\left(\bar{B}^{2}+\bar{B}_{12}^{2}\right)-2 K_{12} \overline{B B}_{12}\right\} \nabla^{4} \bar{w} \\
& =\left(K \bar{B}_{12}+K_{12} \bar{B}\right) \nabla^{4} F \\
& K \nabla^{4} F=-\left(K \bar{B}_{12}+K_{12} \bar{B}\right) \nabla^{4} \bar{w}
\end{aligned}
$$

で与えられる。ここで

$$
\left.\begin{array}{l}
K=\frac{\bar{C}}{\bar{C}^{2}-\bar{C}_{12}^{2}}, K_{12}=-\frac{\bar{C}_{12}}{\bar{C}^{2}-\bar{C}_{12}^{2}} \\
\nabla^{2}=\frac{\partial^{2}}{\partial \xi^{2}}+\frac{1}{\xi} \frac{\partial}{\partial \xi}+\frac{1}{\xi^{2}} \frac{\partial^{2}}{\partial \theta^{2}}
\end{array}\right\}
$$

適合条件式（9）を用いて式（8）の応力関数の項 を消去すると，運動方程式は

$$
\frac{\partial^{2} \bar{w}}{\partial \tau^{2}}+\left(1-\frac{\bar{B}^{2}}{\bar{C}}\right) \nabla^{4} \bar{w}=0
$$

となる.ここで基準面を，面内変位 $u^{0}, v^{0}$ とたわみ $w$ に関する運動方程式が非連成となる $B=0$ の条件より

$$
\bar{\eta}=\sum_{k=1}^{N} H_{k} C_{k} /\left(h \sum_{k=1}^{N} C_{k}\right)
$$

の位置に定める ${ }^{(12)}$ と，積層部分の支配方程式は

$$
\left.\begin{array}{l}
\frac{\partial^{2} \bar{w}}{\partial \tau^{2}}+\nabla^{4} \bar{w}=0 \\
\nabla^{4} F=-\bar{B}_{12} \nabla^{4} \bar{w}
\end{array}\right\}
$$

のように非常に簡単な式となる.

$2 \cdot 2$ はく離部分の支配方程式 はく離部分の第 $k$ 層の諸量を下添字 $k$ を付けて表す.実際には振動中, はく離部分は接触する領域と接触しない領域が混在す るが，本報でははく離界面は全面接触し，界面に相互。 接触力 $q_{k}(r, \theta, t)$ が作用すると仮定して理論解析を行
う. また, 各層のたわみ $w_{k}$ と面内変位 $u_{k}^{0}, v_{k}^{o}$ および その他の諸量を

$$
\left.\begin{array}{l}
\left(\bar{w}_{k}, \bar{u}_{k}^{0}, \bar{v}_{k}^{0}, \bar{d}_{k}, \bar{h}_{k}\right)=\left(w_{k}, u_{k}^{0}, v_{k}^{0}, d_{k}, h_{k}\right) / h \\
\bar{\rho}_{k}=\rho_{k} / \rho,\left(\bar{C}_{k}, \bar{C}_{12 k}\right)=\left(C_{k}, v_{k} C_{k}\right) h^{2} / D \\
\left(\bar{D}_{k}, \bar{D}_{s}, \bar{D}_{12 s}\right)=\left(D_{k}, D_{s}, D_{12 s}\right) / D \\
\bar{q}_{k}=q_{k} R^{4} /(D h)
\end{array}\right\}
$$

と無次元化すると, 各層の微小振幅の曲げ振動に対す る運動方程式は

$$
\left.\begin{array}{l}
\bar{\rho}_{1} \bar{h}_{1} \frac{\partial^{2} \overline{\bar{w}}_{1}}{\partial \tau^{2}}+\bar{D}_{1} \nabla^{4} \bar{w}_{1}+\bar{q}_{1}=0 \\
\bar{\rho}_{k} \bar{h}_{k} \frac{\partial^{2} \bar{w}_{k}}{\partial \tau^{2}}+\bar{D}_{k} \nabla^{4} \bar{w}_{k}+\left(\bar{q}_{k}-\bar{q}_{k-1}\right)=0 \\
\quad(k=2,3, \cdots, N-1) \\
\bar{\rho}_{N} \bar{h}_{N} \frac{\partial^{2} \bar{w}_{N}}{\partial \tau^{2}}+\bar{D}_{N} \nabla^{4} \bar{w}_{N}-\bar{q}_{N-1}=0
\end{array}\right\}
$$

と表される。ここで,これまでと同様に解析解を得る ためにはく離部分の各層のたわみは等しい, すなわち $\bar{w}_{k}=\bar{w}_{1}(k=2,3, \cdots, N)$ と仮定し, 式（15）を加え合わ せると運動方程式は

$$
\frac{\partial^{2} \bar{w}_{1}}{\partial \tau^{2}}+\bar{D}_{s} \nabla^{4} \bar{w}_{1}=0
$$

と簡単な式で表される．また各層のひずみの適合条件 式は, 式 (7) で面内力と応力関数に下添字 $k$ を付けた 関係式を満足する無次元応力関数 $F_{k}$ を用いると

$$
\nabla^{4} F_{k}=0, \quad(k=1,2, \cdots, N)
$$

で与えられる.

\section{3. 解 法}

円板は調和振動すると仮定し，たわみ，面内変位お よび応力関数を, 半径方向の節線の数 $n$ を用いて

$$
\left.\begin{array}{l}
\left(\bar{w}, \bar{w}_{1}, \bar{u}^{0}, \bar{u}_{k}^{0}\right)=\left(X, X_{1}, U, U_{k}\right) \cos (n \theta+\varphi) \sin (\bar{p} \tau+\phi) \\
\left(\bar{v}^{0}, \bar{v}_{k}^{0}\right)=\left(V, V_{k}\right) \sin (n \theta+\varphi) \sin (\bar{p} \tau+\phi) \\
\left(F, F_{k}\right)=\left(\psi, \psi_{k}\right) \cos (n \theta+\varphi) \sin (\bar{p} \tau+\phi)
\end{array}\right\}
$$

とおくと, 式（13）と式（16），(17）は

$$
\left.\begin{array}{ll}
\left(\nabla_{d}^{2}+\lambda^{2}\right)\left(\nabla_{d}^{2}-\lambda^{2}\right) X=0, & \nabla_{d}^{4} \psi=-\bar{B}_{12} \nabla_{d}^{4} X \\
\left(\nabla_{d}^{2}+\lambda_{1}^{2}\right)\left(\nabla_{d}^{2}-\lambda_{1}^{2}\right) X_{1}=0, & \nabla_{d}^{4} \psi_{k}=0
\end{array}\right\}
$$

となる.ただし

$$
\left.\begin{array}{l}
\nabla_{d}^{2}=\frac{d^{2}}{d \xi^{2}}+\frac{1}{\xi} \frac{d}{d \xi}-\frac{n^{2}}{\xi^{2}} \\
\lambda^{2}=\bar{p}, \quad \lambda_{1}^{2}=\bar{p} / \sqrt{\bar{D}_{s}}
\end{array}\right\}
$$


式（19）より $X_{1}$ が $\xi=0$ で有界な解をもつことを考慮 すると, $X$ と $X_{1}$ は

$$
\begin{aligned}
X(\xi)= & A_{1} J_{n}(\lambda \xi)+A_{2} Y_{n}(\lambda \xi) \\
& +A_{3} I_{n}(\lambda \xi)+A_{4} K_{n}(\lambda \xi) \\
X_{1}(\xi) & =A_{11} J_{n}\left(\lambda_{1} \xi\right)+A_{13} I_{n}\left(\lambda_{1} \xi\right)
\end{aligned}
$$

となる.ここで, $J_{n}, Y_{n}$ は $n$ 次の第 1 種, 第 2 種の Bessel 関数, $I_{n}, K_{n}$ は $n$ 次の第 1 種，第 2 種の変形 Bessel 関数である. また，積層部分の応力関数の一般解は式

（19）の第 2 式より補助解を $\Psi_{c}$ とすると

$$
\psi(\xi)=\psi_{c}(\xi)-\bar{B}_{12} X
$$

で与えられる，次に，境界条件と連続条件で必要とな る基準面の面内変位 $\bar{u}^{0}, \bar{v}^{0}$ を求めておく. $\bar{u}^{0}$ と $\bar{v}^{0}$ は 式（3）および式（2）より

$$
\begin{aligned}
\frac{\partial \bar{u}^{0}}{\partial \xi}= & \frac{h}{R}\left[K \bar{N}_{r}+K_{12} \bar{N}_{\theta}+\bar{B}_{12}\left\{K_{12} \frac{\partial^{2} \bar{w}}{\partial \xi^{2}}\right.\right. \\
& \left.\left.+K\left(\frac{1}{\xi} \frac{\partial \bar{w}}{\partial \xi}+\frac{1}{\xi^{2}} \frac{\partial^{2} \bar{w}}{\partial \theta^{2}}\right)\right\}\right] \\
\frac{\partial \bar{\nu}^{0}}{\partial \theta}= & \frac{h}{R} \xi\left[K_{12} \bar{N}_{r}+K \bar{N}_{\theta}+\bar{B}_{12}\left\{K \frac{\partial^{2} \bar{w}}{\partial \xi^{2}}\right.\right. \\
& \left.+K_{12}\left(\frac{1}{\xi} \frac{\partial \bar{w}}{\partial \xi}+\frac{1}{\xi^{2}} \frac{\partial^{2} \bar{w}}{\partial \theta^{2}}\right)\right\}-\bar{u}^{0}
\end{aligned}
$$

と表せるので, 式（7）の面内力を代入し，式（18）と 式（23）の関係を用いると

$$
\left.\begin{array}{l}
U(\xi)=\int \frac{h}{R}\left[K_{12} \frac{d^{2} \psi_{c}}{d \xi^{2}}+K\left(\frac{1}{\xi} \frac{d \psi_{c}}{d \xi}-\frac{n^{2}}{\xi^{2}} \psi_{c}\right)\right] d \xi \\
V(\xi)=\frac{1}{n}\left[\frac{h}{R} \xi\left\{K \frac{d^{2} \psi_{c}}{d \xi^{2}}+K_{12}\left(\frac{1}{\xi} \frac{d \psi_{c}}{d \xi}-\frac{n^{2}}{\xi^{2}} \psi_{c}\right)\right\}-U\right]
\end{array}\right\}
$$

が得られる.はく離部分の面内変位 $U_{k}$ と $V_{k}$ は, 式 (24) で $\Psi_{c}$ を $\Psi_{k}$ に, $K$ 亡 $K_{12}$ を $K_{k}$ と $K_{12 k}$ に書き換えれば求 められる.ただし， $K_{k}$ と $K_{12 k}$ は

$$
K_{k}=\frac{\bar{C}_{k}}{\bar{C}_{k}^{2}-\bar{C}_{12 k}^{2}}, \quad K_{12 k}=-\frac{\bar{C}_{12 k}}{\bar{C}_{k}^{2}-\bar{C}_{12 k}^{2}}
$$

ところで, 応力関数 $F, F_{k}$ を表す $\Psi(\xi)$ と $\Psi_{k}(\xi)$ は, 式 (19) および式（20）の微分演算子 $\nabla_{d}^{2}$ からわかるように, $n=0$ の場合と $n=1,2, \cdots$ 場合では異なつた式となる: そこで非軸対称振動 $(n=1,2, \cdots)$ と軸対称振動 $(n=0)$ に分けて理論解析を行う.
$3 \cdot 1$ 非軸対称振動 $(n=1,2, \cdots) \quad \xi=0$ の円板の 中心で面内力 $\bar{N}_{r k}$ ，すなわち

$$
\bar{N}_{r k}=\frac{1}{\xi} \frac{\partial F_{k}}{\partial \xi}+\frac{1}{\xi^{2}} \frac{\partial^{2} F_{k}}{\partial \theta^{2}}
$$

が有界であるという条件を用いると，積層部分の応力 関数の補助解 $\Psi_{c}$ とはく離部分の応力関数 $\Psi_{k}$ は

$$
\begin{aligned}
& \psi_{c}(\xi)=A_{31} \xi^{-n}+A_{32} \xi^{-(n-2)}+A_{33} \xi^{n+2}+A_{34} \xi^{n} \\
& \psi_{k}(\xi)=A_{53 k} \xi^{n+2}+A_{54 k} \xi^{n},(k=1,2, \cdots, N)
\end{aligned}
$$

と求められる. 式 (21)，(22）および式 (27) 加ら未 定定数は $10+2 \mathrm{~N}$ 個となることがわかる. 面内変位は式

（27）を式（24）に代入し，Uについてはさらに積分 して岡体変位を表す積分定数の項を落とすと（16)

$$
\begin{aligned}
U(\xi)= & (h / R)\left[A_{31}\left(K-K_{12}\right) n \xi^{-(n+1)}\right. \\
& +A_{32}\left\{(n+2) K-(n-2) K_{12}\right\} \xi^{-(n-1)} \\
& -A_{33}\left\{(n-2) K-(n+2) K_{12}\right\} \xi^{n+1} \\
& \left.-A_{34}\left(K-K_{12}\right) n \xi^{n-1}\right] \\
V(\xi)= & (h / R)\left[A_{31}\left(K-K_{12}\right) n \xi^{-(n+1)}\right. \\
& +A_{32}\left\{(n-4) K-n K_{12}\right\} \xi^{-(n-1)} \\
& +A_{33}\left\{(n+4) K-n K_{12}\right\} \xi^{n+1} \\
& \left.+A_{34}\left(K-K_{12}\right) n \xi^{n-1}\right] \\
U_{k}(\xi)= & (h / R)\left[A_{53 k}\left\{-(n-2) K_{k}+(n+2) K_{12 k}\right\} \xi^{n+1}\right. \\
& \left.-A_{54 k}\left(K_{k}-K_{12 k}\right) n \xi^{n-1}\right] \\
V_{k}(\xi)= & (h / R)\left[A_{53 k}\{(n+4)\} K_{k}-n K_{12 k}\right\} \xi^{n+1} \\
& \left.+A_{54 k}\left(K_{k}-K_{12 k}\right) n \xi^{n-1}\right]
\end{aligned}
$$

で与えられる.

次に，本報では全周辺固定で面内不動周辺の円板を 取り上げるので，境界条件は

$$
\xi=1 \text { で } \quad X=0, \frac{d X}{d \xi}=0, U=0, V=0
$$

となる，また，はく離円周縁における変位とたわ角 に関する連続条件は

$$
\begin{aligned}
& \xi=\bar{c} \text { で } \quad X=X_{1}, \frac{d X}{d \xi}=\frac{d X_{1}}{d \xi}, U-\frac{h}{R} \bar{d}_{k} \frac{d X}{d \xi}=U_{k} \\
& V+n \frac{h}{R} \frac{\bar{d}_{k}}{\xi} X=V_{k},(k=1,2, \cdots, N)
\end{aligned}
$$

曲げモーメントとせん断力の連続条件は

$$
\begin{aligned}
\xi=\bar{c} & \\
& \frac{d^{2} X}{d \xi^{2}}+\bar{D}_{12}\left(\frac{1}{\xi} \frac{d X}{d \xi}-\frac{n^{2}}{\xi^{2}} X\right)
\end{aligned}
$$




$$
\begin{aligned}
&-\bar{B}_{12}\left[K \frac{d^{2} \psi_{c}}{d \xi^{2}}+K_{12}\left(\frac{1}{\xi} \frac{d \psi_{c}}{d \xi}-\frac{n^{2}}{\xi^{2}} \psi_{c}\right)\right] \\
&= \bar{D}_{s} \frac{d^{2} X_{1}}{d \xi^{2}}+\bar{D}_{12 s}\left(\frac{1}{\xi} \frac{d X_{1}}{d \xi}-\frac{n^{2}}{\xi^{2}} X_{1}\right) \\
&-\sum_{k=1}^{N} d_{k}\left(\frac{1}{\xi} \frac{d \psi_{k}}{d \xi}-\frac{n^{2}}{\xi^{2}} \psi_{k}\right) \\
& \frac{d}{d \xi}\left(\nabla_{d}^{2} X\right)-K \bar{B}_{12} \frac{d}{d \xi}\left(\nabla_{d}^{2} \psi_{c}\right)=\bar{D}_{s} \frac{d}{d \xi}\left(\nabla_{d}^{2} X_{1}\right)
\end{aligned}
$$

面内力 $N_{r}$ と $N_{r \theta}$ の連続条件は

$$
\xi=\bar{c} \text { で }
$$

$$
\begin{aligned}
& \frac{1}{\xi} \frac{d \psi}{d \xi}-\frac{n^{2}}{\xi^{2}} \psi=\sum_{k=1}^{N}\left(\frac{1}{\xi} \frac{d \psi_{k}}{d \xi}-\frac{n^{2}}{\xi^{2}} \psi_{k}\right) \\
& \frac{n}{\xi} \frac{d \psi}{d \xi}-\frac{n}{\xi^{2}} \psi=\sum_{k=1}^{N}\left(\frac{n}{\xi} \frac{d \psi_{k}}{d \xi}-\frac{n}{\xi^{2}} \psi_{k}\right)
\end{aligned}
$$

これらの条件を各固有関数に適用し，面内変位の境界 条件と連続条件から $A_{31}, A_{34}$ と $A_{53 k}, A_{54 k}$ を求めて消去 すると

$$
[H]\{A\}=\{0\}
$$

の関係式得られる.ここで $\{A\}$ は

$$
\{A\}=\left\{A_{1}, A_{2}, A_{3}, A_{4}, A_{11}, A_{13}, A_{32}, A_{33}\right\}^{T}
$$

であり, $[H]$ は 8 行 8 列の正方マトリックスである. 式 （35）から振動数方程式

$$
|H|=0
$$

が得られる.

$3 \cdot 2$ 軸対称振動 $(n=0)$ 軸対称振動の場合, た わみの固有関数 $X, X_{1}$ は, 式 (21)，(22) で $n=0$ とおい た 0 次の Bessel 関数と変形 Bessel 関数で表される. ま た, $n=0$ とおいた式（19）から $\Psi ， \Psi_{\mathrm{k}}$ を求めると定数 項が表われる. しかしながら，境界条件や連続条件で 用いる $\bar{N}_{r} や \bar{N}_{\theta}$ などは式 (7) より応力関数を $\xi$ で偏微 分して得られる. したがって， $\xi=0 て ゙ \bar{N}_{r k}$ が有界ある という条件を用いて式 (19) から得られる $\Psi_{\mathrm{c}}$ と $\Psi_{\mathrm{k}}$ で, 定数項を落とすと

$$
\left.\begin{array}{l}
\psi_{c}(\xi)=A_{22} \xi^{2}+A_{23} \log \xi+A_{24} \xi^{2} \log \xi \\
\psi_{k}(\xi)=A_{42 k} \xi^{2} \quad,(k=1,2, \cdots, N)
\end{array}\right\}
$$

が求められ，末定定数は $9+\mathrm{N}$ 個となる. 面内変位は, 上式を式（24）に代入して積分すると

$$
\begin{aligned}
U(\xi)= & (h / R)\left[2 A_{22}\left(K+K_{12}\right) \xi-A_{23}\left(K-K_{12}\right) \xi^{-1}\right. \\
& \left.+A_{24}\left\{K(2 \log \xi-1)+K_{12}(2 \log \xi+1)\right\} \xi\right] \\
U_{k}(\xi)= & 2 A_{42 k}(h / R)\left(K_{k}+K_{12 k}\right) \xi
\end{aligned}
$$

と表される. 軸対称振動の場合，境界条件（29） と連続条件 (30) で，Vに関する条件式讨不要で ある. また $N_{r \theta}$ は 0 となるため, $n=0$ とおいた式 (31)， (32)， (33)の曲げモーメント, せ九断力, 面内力 $N_{r}$ の連続条件に加えて, 面内力 $N_{\theta}$ に関す る次の連続条件を採用する.

$$
\frac{d^{2} \psi}{d \xi^{2}}=\sum_{k=1}^{N} \frac{d^{2} \psi_{k}}{d \xi^{2}}
$$

面内変位の境界条件と連続条件から $A_{22}$ と $A_{42 k}$ を求め て消去すると

$$
\left.\begin{array}{l}
{[Y]\{A\}=\{0\}} \\
\{A\}=\left\{A_{1}, A_{2}, A_{3}, A_{4}, A_{11}, A_{13}, A_{23}, A_{24}\right\}^{T}
\end{array}\right\}
$$

の関係が得られ，これより振動数方程式は

$$
|Y|=0
$$

となる.

\section{4. 実験および計算結果}

大きさの等しい三重の層間はく離を有する四層の積

Table 1 Material properties

\begin{tabular}{|c|c|c|c|}
\hline Materials & $E[\mathrm{GPa}]$ & $v$ & $\rho\left[\mathrm{kg} / \mathrm{m}^{3}\right]$ \\
\hline Aluminum & 72.4 & 0.33 & 2700 \\
\hline Tough pitch copper & 114 & 0.35 & 8600 \\
\hline Stainless spring steel & 194 & 0.30 & 7770 \\
\hline
\end{tabular}

Table 2 Test-Piece

\begin{tabular}{|c|c|c|c|c|c|c|}
\hline $\mathrm{k}$ & Plate $1^{(11)}$ & $\mathrm{h}_{\mathrm{k}}[\mathrm{mm}]$ & Plate $2^{(12)}$ & $\mathrm{h}_{\mathrm{k}}[\mathrm{mm}]$ & Plate 3 & $\mathrm{h}_{\mathrm{k}}[\mathrm{mm}]$ \\
\hline 1 & Steel & 0.7 & Steel & 0.2 & Steel & 0.2 \\
\hline 2 & Copper & 0.3 & Copper & 0.6 & Aluminum & 0.4 \\
\hline 3 & & & Aluminum & 0.2 & Copper & 0.1 \\
\hline 4 & & & & & Steel & 0.2 \\
\hline
\end{tabular}


層円板を前報 ${ }^{(13)}$ と同様に製作し，高次振動の実験も行 つて固有振動数の実験值と理論結果を比較し，解析モ デルの妥当性を検証した.

\section{$4 \cdot 1$ 試験片と実験要領＼cjkstart試験片の外形寸法は一} 辺が 200mm の正方形である. まず同じ寸法の透明な アクリル板を使用してシアノアクリレート系瞬間接着 剤の適切な貼付位置と量を試行錯誤で取得した。さら にこの方法で, 表 1 の材料定数をもつ表 2 の Plate 3 の 各層の板を接着し, 重りを約 24 時間載せて接着部分に むらがなく，しかもほぼ所定のはく離半径をもつ試験 片を製作した. なお，二層の Plate 1 は文献（11）で, 三層の Plate 2 は文献（12）で使用した試験片である.

試験片取付枠は, 大きさが $250 \mathrm{~mm}$ 角で愿さが $20 \mathrm{~mm}$ の2枚の鉄板のそれぞれ中心部に半径 $R=80 \mathrm{~mm}$ の開口 部を設け，試験片接触面を研摩仕上げして製作した. 試験片はこの取付枠に挟んで 12 本のボルトで取付け た. 実験は次の手順で行った.まず試験片を挟んだ試 験片取付枠を，定盤の上に設置した固定枠台に垂直に 固定した．加振方法はスピーカーによる音響加振法を 採用した. 口径 $120 \mathrm{~mm}$ のスピーカーに直径 $10 \mathrm{~mm}$ の 先端開口をもつアルミ製のホーン型ノズルを取付け, 音圧による加振領域ができるだけ節直径の位置を避け て板の最大振幅点付近になるようにスピーカ一を設定 した．試験片の応答は，これまで拡散反射タイプの半 導体レーザーを用いた変位計(11) ${ }^{(12) や ひ す ゙ み ケ ゙ ー シ ゙(13) ~}$ を用いて測定してきたが，今回四層でしかも高次モ一 ドの振動応答を測定するため, 感度もよくノイズの少 ない圧電素子を用いた. 圧電素子は大きさが $3.0 \mathrm{~mm} \times$

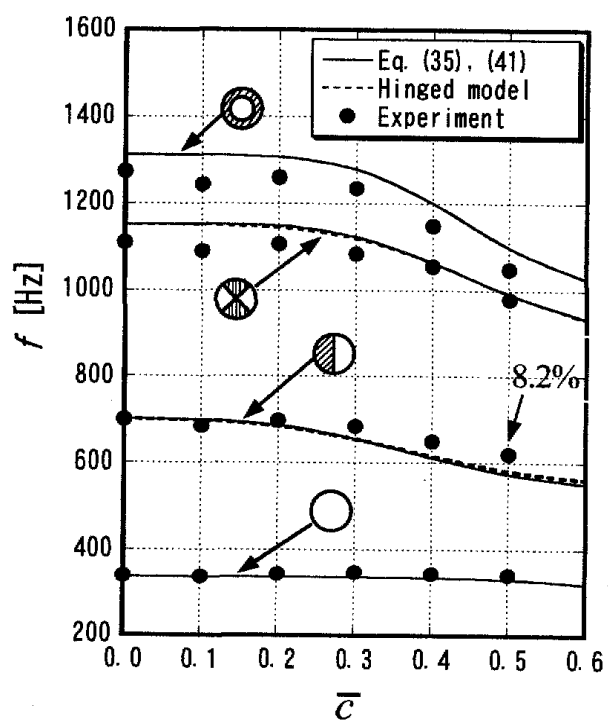

(a) Plate $1 \quad(\mathrm{~N}=2)$
$10.0 \mathrm{~mm}$, 厚さ約 $0.3 \mathrm{~mm}$ で, 応力出力電圧はアンプを 通さずその端子から直接シンクロスコープに入力して 測定することができる．振動実験ではまず，加振振動 数を変化させ, 加振用のスピーカ一端子電圧と試験片 に接着した圧電素子の応答出力電圧とでリサジュ一図 形を描かせて共振点を検出し，固有振動数を測定した。 なお振動モ一ドは，振動中の板を指でなぞって節直径 の位置と数を確認して判断した.

$4 \cdot 2$ 固有振動数 節值径数を $n$, 節円数を $s$ とす る.まず，はく離半径至が零に近づくと, 式 (37) と 式（43）から得られる無次元角固有振動数 $\bar{p}$ の值は, $(n, s)=(0,0),(1,0),(2,0),(0,1)$ の各モ一ドに対して

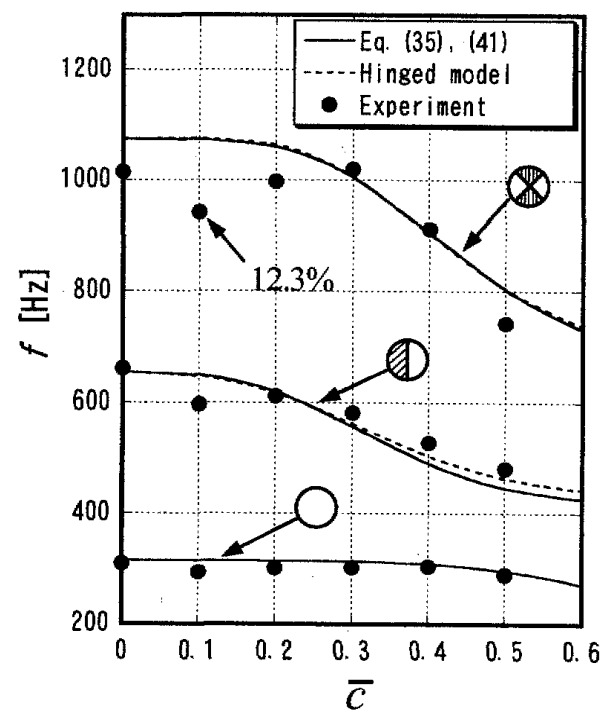

(b) Plate $2 \quad(\mathrm{~N}=3)$

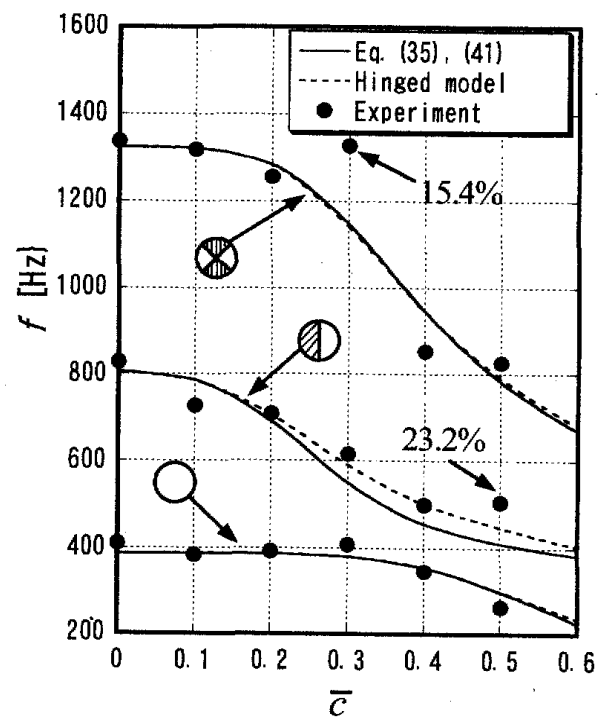

(c) Plate $3 \quad(\mathrm{~N}=4)$

Fig. 2 Comparison between experimental and theoretical friquencies 
$10.22,21.26,34.88,39.77$ となって等力均質な固定円板 の值 ${ }^{(17)}$ 上一致する. 図 2 は

$$
f=\frac{1}{2 \pi} \frac{\bar{p}}{R^{2}} \sqrt{\frac{D}{\rho h}}
$$

で計算される固有振動数 $f[\mathrm{~Hz}]$ を縦軸に，無次元はく 離半径 $\bar{c}=c / R$ を横軸にとって, 実験值と理論結果を 比較したものである.図中の・は㬰験值, 実線は式 (37) と式 (43) で計算した面内変形の影響を考慮した固有 振動数, 点線は前報 ${ }^{(13)}$ の式（25）のヒンジモデルによ る固有振動数である. なお図 2(a) と(b)の実験值は, 文 献（11）の図6(a) と文献 (12) の図 5(d)の結果である. まず, 図2（c）の $\bar{c}=0$ の完全に接着された積層円 板の固有振動数に着目してみると，実験值 $411.0 \mathrm{~Hz}$, $828.7 \mathrm{~Hz}, 1337.3 \mathrm{~Hz}$ は接着層の影響を考慮していない 理論振動数は $388.0 \mathrm{~Hz}, 807.4 \mathrm{~Hz}, 1324.6 \mathrm{~Hz}$ とほぼ一致 している.このことから，今回の実験でも試験片の接 着層が固有振動数に与える影響はほとんど認められな いものと思われる，次に各試験片に対して，面内変形 の影響を考慮した実線の理論振動数と害験値との最大 誤差を調べてみる，その際，同じ塞験值に対する点線

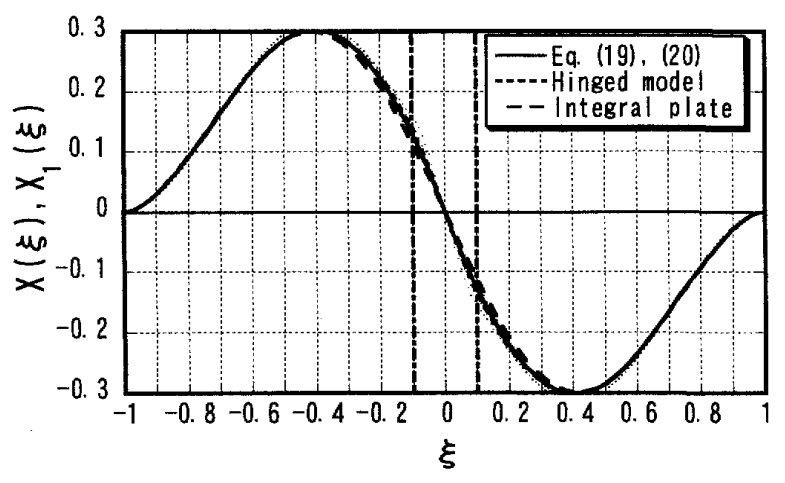

(a) $\bar{c}=0.1$

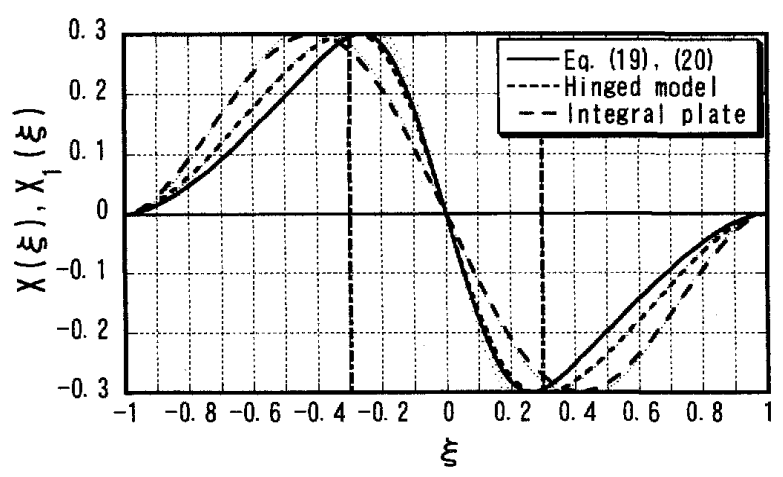

(b) $\bar{c}=0.3$

Fig. 3 Mode shape (Plate $3, n=1, s=0$ )
のヒンジモデルで求めた振動数との誤差をカッコ内の 数值で示す. 最大誤差は, (a)図の二層板では $8.2 \%$ (6.7\%), (b)図の三層板では $12.3 \%(12.4 \%)$, (c)図の四層

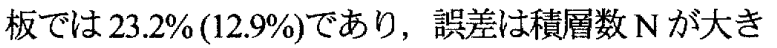
くなるにつれて生じやすい傾向にある.これは，積層 数Nが大きくなると所定のはく離を有する試験片の製 作が難しく，かつ応答出力が小さく正確な共振振動数 が計測しづらかったためである.しかし，何点かの測 定結果を除くと, 理論解析で得られた固有振動数と実 験值はよく一致し，本報の解析モデルの妥当性が確認 できる.また，解析が非常に簡単な前報 ${ }^{(13)}$ のヒンジモ デルによる理論曲線は，本報の面内変形を考慮した理 論曲線とほぼ一致し，はく離を有する異種材積層円板 の固有振動数に及ぼす面内変形の影響は小さい. しか し，積層数 N がさらに増加すると，両理論值の相違は 大きくなることが予想される.

$4 \cdot 3$ 固有振動モード 図 2(c)の Plate3(N=4)の $(n, s)=(1,0)$ モードでは, 式 (37) で計算した振動数が 前報 ${ }^{(13)}$ のヒンジモデルによる振動数に比べて $\bar{c}=0.3 \sim$ 0.5 付近で 7 10\%程度低くなっている. そこで，半径 $\bar{c}=c / R=0.1$ と 0.3 のはく離をもつPlate 3 の, 最大振 幅を 0.3 と正規化した $(1,0)$ の振動モ一ドを図 3 に示 す. 図中の縦の一点鎖線は, はく離端を表す. $\bar{c}=0.1$ のはく離が小さい場合，振動モ一ドに及ぼすはく離の 影響はほとんど見受けられない.ところが $\bar{c}=0.3$ とは く離が大きくなると，たわみ曲線が破線のはく離のな い板に比べてはく離の中心方向へ移動し，その傾向は 面内変形の影響を考慮した実線の振動モードの方がヒ ンジモデルによる点線の振動モ一ドに比べて大きい. このことは, 面内変形の影響を考慮した固有振動数が ヒンジモデルによる振動数に比べて低くなるという傾 占と合致するものといえる.なお， $(0,0) ，(2,0)$ モ一 ドの場合の両理論による振動モ一ドははく離半径の大 きさに関係なくほとんど一致した。

\section{5.むすび}

本報では， $\mathrm{N}$ 層の異種材積層円板がその中心部に大 きさの等しい円形の多重層間はく離を有する場合の自 由振動を, 面内の慣性力は無視できるものとして応力 関数を導入し，面内変形の影響を考慮した理論解析を 行った.ただし，これまでの報告(12)(13) と同じように， 解析解を求めるために，はく離部分の各層のたわみは 等しいと仮定している. そこで，大きさの等しいはく 離を有する四層の積層円板を製作して振動実験を行い， 理論結果がこれまでの報告の二層板 ${ }^{(11)}$ ，三層板 ${ }^{(12) お よ ~}$ 
び今回の四層板の測定した固有振動数とよく一致する ことを確認した．また，面内変形を無視して，はく離 円周縁をヒンジ此めと仮定した前報(13)の解析モデル の固有振動数と固有振動モ一ドは，面内変形の影響を 考慮した本報の理論結果しほぼ一致した.したがって, 前報 ${ }^{(13)}$ のヒンジモデルは，積層円板の自由振動特性に 及ぼすはく離の影響を調査する場合には，簡単でしか も有効な力法といえる. 将来的にはヒンジモデルによ る理論解析を，工業的に重要と考えられる大きさの異 なる多重層間はく離を有する積層長方形板の振動問題 へ展開させるつもりである.

\section{文 献}

(1) Wang, J. T. S. et al., Vibrations of Split Beams, Journal of Sound and Vibration, Vol. 84, No. 4(1982), pp. 491-502.

(2) Mujumdar, P. M. and Suryanarayan, S., Flexural Vibrations of Beams with Delaminations, Journal of Sound and Vibrations, Vol. 125, No. 3 (1988), pp. 441-461.

(3) Tracy, J. J. and Pardoen, G. C., Effect of Delamination on the Natural Frequencies of Composite Laminates, Journal of Composite Materials, Vol. 23, No. 12 (1989), pp. 1200-1215.

(4) Shen, M. H. and Grady, J. E., Free Vibrations of Delaminated Beams, AIAA Journal, Vol. 30 , No. 5 (1992), pp. 1361-1370.

(5) Hu, J. S. and Hwu, C., Free Vibrations of Delaminated Composite Sandwich Beams, AIAA Journal, Vol. 33, No. 10 (1995), pp. 1911-1918.

(6) Chang, T.-P. and Liang, J.-Y., Vibration of Postbuckled Delaminated Beam-Plates, International Journal of Solids and Structures, Vol. 35, No. 12 (1998), pp. 1199-1217.

(7) Aritomi, M. et al., Free Vibrations of Laminated Beams Containing a Delamination, Transactions of the Japan Society of Mechanical Engineers, Serie C, Vol. 65 , No. 638 (1999), pp. 3943-395
(8) Luo, H. and Hanagud, S., Dynamics of delaminated beams, International Journal of Solids and Structures, Vol. 37 (2000), pp. 1501-1519.

(9) Sekine, H. et al., Impact Response Analysis of Partially Delaminated Composite Laminates, Transactions of the Japan Society of Mechanical Engineers, Series A, Vol. 63, No. 608 (1997), pp. 787-793.

(10) Aritomi, M. et al., Axisymmetric Free Vibrations of Circular Laminated Plates Containing a Disk-Shaped Delamination, Transactions of the Japan Society of Mechanical Engineers, Series C, Vol. 67, No. 654 (2001), pp. 300-308.

(11) Aritomi, M. et al., Free Vibration Characteristics of Circular Laminated Plates Containing a Disk-Shaped Delamination, Transactions of the Japan Society of Mechanical Engineers, Series C, Vol. 67, No. 662 (2001), pp. 3108-3115.

(12) Aritomi, M. et al., Free Vibrations of Circular Laminated Plates Containing Double Delaminations of Different Sizes, Transactions of the Japan Society of Mechanical Engineers, Series C, Vol. 72, No. 719(2006), pp. 2027-2033.

(13) Aritomi, M. et al., Free Vibrations of Circular Laminated Plates Containing Multiple Delaminations of a Same Sizes, Transactions of the Japan Society of Mechanical Engineers, Series C, Vol. 73, No. 736(2007), pp. 3151-3158.

(14) Suemasu, H. and Majima, O., Multiple Delaminations and Their Severity in Circular Axisymmetric Plates Subjected to Transverse Loading, Journal of Composite Materials, Vol. 30, No. 4 (1996), pp. 441-453.

(15) Suemasu, H. and Majima, O., Multiple Delaminations and Their Severity in Nonlinear Circular Plates Subjected to Concentrated Loading, Journal of Composite Materials, Vol. 32, No. 2 (1998), pp. 123-140.

(16) Chia,C,Y., Nonlinear Analysis of Plates, (1980), p.18, p.33,McGraw-Hill.

(17) Sekiya, S. et al, Design Handbook for Plate Structure (in Japanese), (1982), p.170, Asakura shoten. 